\title{
PENGEMBANGAN BIOELECTRICAL IMPEDANCE SEBAGAI CONTROL COMMANDS PENGATURAN KECEPATAN GERAK KURSI RODA DENGAN METODA PID CONTROLLER
}

\author{
Juli Sardi *, Ali Basrah Pulungan ** \\ *Jurusan Teknik Elektro UNP, Padang25171, e-mail: juli_sardi@yahoo.com \\ **Jurusan Teknik Elektro UNP, Padang25171, e-mail: alibp@ft.unp.ac.id
}

\begin{abstract}
Abstrak - Penelitian ini memanfaatkan sinyal bioimpedance tubuh untuk mengatur kecepatan gerak kursi roda.Bioimpedance adalah bagian elektrik pasif yang terdapat pada jaringan tubuh.Hasil penelitian ini dapat dijadikan sebagai salah satu solusi bagi penderita kelumpuhan untuk membantu mobilisasi.Penelitian ini diawali dengan perancangan sistem yang meliputi alat ukur bioimpedance dan desain mekanik dari kursi roda. Pengukuran bioimpedance dilakukan dengan menginjeksikan sumber arus sinusoidal sebesar $0,5 \mathrm{~mA}_{\text {rms }}$ dengan frekuensi $50 \mathrm{kHz}$ ke jaringan otot tubuh (punggung) sehingga didapatkan tegangan keluaran yang berkisar antara $0-5 \mathrm{Vdc}$. Dengan metode impulse dan manual thresholding, tegangan diklasifikasikan menjadi beberapa sinyal kontrol untuk mengatur kecepatan dan arah kursi roda berdasarkan metodePID Controller. Hasil yang didapatkan dari penelitian ini adalah terealisasikannya sinyal bioimpedance yang digunakan sebagai referensi dalam mengontrol arah dan kecepatan dari kursi roda dengan tingkat keberhasilan 86.7 \%.Kecepatan gerak kursi roda diklasifikasikan kedalam tiga jenis kecepatan, yaitu kecepatan lambat, sedang dan cepat. Kecepatan lambat memiliki nilai kecepatan sebesar $30 \mathrm{Cm} / \mathrm{s}$. Kecepatan sedang memiliki nilai kecepatan sebesar $40 \mathrm{Cm} / \mathrm{s}$. Sedangkan kecepatan cepat memiliki nilai kecepatan sebesar $50 \mathrm{Cm} / \mathrm{s}$. Selain bergerak lurus, kursi roda juga bisa berbelok ke arah kiri dan kanan sesuai dengan keinginan dari pengguna kursi roda.
\end{abstract}

Kata Kunci :Bioimpedance, Kursi Roda, PID Controller

\begin{abstract}
In the present study, bioimpedance signals of human body was utilized to control speed of a wheelchair movement. A bioimpedance is electrically passive part contained the body tissues. The research is one of alternative solutions for patients with paralysis of the upper and lower limb. Firstly, design of system of the research consisted of bioimpedance measuring instruments and a mechanical design of the wheelchair. Bioimpedance measurement was performed by injecting a sinusoidal current source of $0.5 \mathrm{mArms}$ with a frequency of $50 \mathrm{kHz}$ to muscle tissue (shoulder) to obtain the output voltage in the range of $0-5 \mathrm{Vdc}$. With impulse and manual thresholding methods, the voltage signal was classified into several controls command to adjust the speed and direction of the wheelchair control based on PID Controller. The experimental result of the research was realization of bioimpedance signal that used as a reference to control the direction and speed of the wheelchair with a success rate of $86.7 \%$. A wheelchair velocity was classified into three types of motion, namely slow, medium and fast. Slow speed has a rated speed of $30 \mathrm{Cm} / \mathrm{s}$, medium speed value speed of $40 \mathrm{Cm} / \mathrm{s}$ and fast speed value of $50 \mathrm{Cm} / \mathrm{s}$. The wheelchair can also turn to the left and the right in accordance with the wishes of wheelchair user beside to moving forward.
\end{abstract}

Keywords :Bioimpedance, Wheel Chair, PID Controller

\section{PENDAHULUAN}

Penderita kelumpuhan akan kesulitan dalam melakukan mobilisasi, maka untuk berpindah dari satu tempat ke tempat yang lain, penderita memerlukan suatu alat bantu. Alat bantu yang sering digunakan yaitu kursi roda. Namun, bagi penderita yang mengalami disfungsi alat gerak bagian atas dan bawah (upper limb dan lower limb), kursi roda konvensional tidak lagi bisa membantu karena penderita tidak mampu menggunakan lengannya untuk menggerakkan kursi roda tersebut. Oleh sebab itu, perlu dipikirkan cara lain untuk membantu penderita yang mengalami kelumpuhan tersebut agar bisa melakukan mobilisasi dengan menggunakan kursi roda.

Salah satu alternatif yang bisa digunakan adalah dengan memanfaatkan sinyal bioimpedance tubuh untuk mengontrol gerakan kursi roda.Perubahan nilai bioimpedance ini bergantung pada pergerakan yang dilakukan 
oleh bagian tubuh tertentu. Dengan adanya perubahan nilai bioimpedance, kita bisa menggunakannya sebagai input atau referensi pada suatu sistem. Oleh karena itu, potensi penggunaan sinyal bioimpedance sebagai perintah kontrol (control commands) untuk mengendalikan kursi roda menggantikan peran tangan manusia sangat besar.

Belakangan ini telah dilakukan berbagai penelitian terkait dengan sinyal bioimpedance tubuh.Salah satu pencapaian yang didapatkan adalah sinyal bioimpedance ini telah berhasil digunakan untuk menggerakkan kursi roda dengan beberapa gerakan sederhana, seperti gerakan maju, belok kiri dan belok kanan [2].Namun, masih terdapat berbagai permasalahan sehingga belum layak digunakan oleh penderita yang mengalami kelumpuhan. Pada penelitian ini, kami mencoba menampilkan hasil eksperimen terhadap output sinyal bioimpdance yang dijadikan perintah kontrol (control commands) untuk mengatur kecepatan dari kursi roda.

\section{LANDASAN TEORI}

Seluruh material, termasuk jaringan tubuh, memiliki sejumlah sifat listrik yang berbeda-beda.Bioimpedance mengacu pada perlawanan dari aliran arus yang melalui jaringan tubuh [3].Sel tubuh terdiri dari dua bagian yaitu intraseluler dan ekstraseluler.Membran sel dalam kumpulan intraseluler menentukan besar reaktansi.Model pendekatan rangkaian elektronika dari tiap sel dapat dilihat seperti Gambar 1 [3].jaringan tubuh merupakan gabungan dari banyak sel dengan besar dan komposisi yang berbeda menjadi sebuah ionic salt dissolution.Model pendekatan elektronik dari suatu jaringan tubuh seperti pada Gambar 2 [3].Bagian elektrik pasif yang terdapat pada jaringan tubuh disebut dengan bioimpedance. Untuk mengukur besarnya bioimpedance, pada bagian tubuh tertentu harus dialiri arus listrik yang kecil melalui suatu elektroda. Besar bioimpedance yang terukur bisa diketahui dengan menggunakan hukum Ohm[3].

$\mathrm{Z}=\frac{V}{I}$, Dimana $\mathrm{V}$ adalah tegangan dan I adalah arus

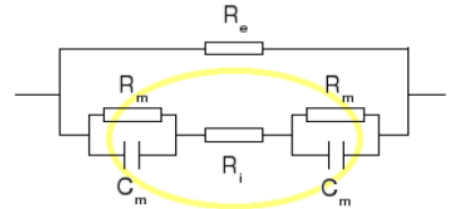

Gambar 1.Model pendekatan rangkaian elektronika dari sel

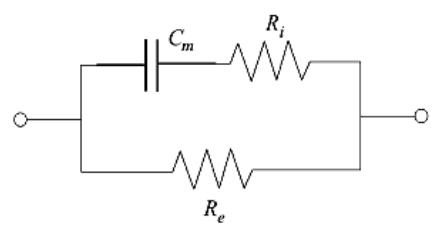

Gambar 2: Model pendekatan elektronika dari suatu jaringan tubuh

Keterangan :

$\mathrm{R}_{\mathrm{i}} \quad$ : Intracellular Resistance

$\mathrm{C}_{\mathrm{m}} \quad$ : Intracellular Reactance

$\mathrm{R}_{\mathrm{e}} \quad$ : Extracellular Resistance

\section{METODA}

\section{A. Pengukuran Bioimpedance}

Pengukuran bioimpedance dilakukan pada bagian bahu (punggung), karena pengukuran bioimpedance yang paling optimal terdapat pada bagian tersebut[2]. Metode pengukuran bioimpedance yang dilakukan yaitu dengan metode empat elektroda, tetapi terdapat sedikit modifikasi. Pada umumnya metode empat elektroda memerlukan 6 buah elektroda untuk dua kanal, namun pada aplikasi ini hanya akan digunakan tiga buah elektroda. Elektroda 1 dan 2 digunakan untuk stimulasi arus dan masing-masing juga digunakan sebagai detektor tegangan. Elektroda nomor 3 bertindak sebagai ground dari kedua kanal[4]. Konfigurasi pemasangan elektroda diperlihatkan pada Gambar 3 [4].

Elektroda akan diletakkan di daerah punggung, tepatnya yaitu pada jaringan otot trapezius (titik v1 dan v2). Titik 3 digunakan sebagai referensi. Tegangan yang akan diukur oleh rangkaian instrumentasi yaitu antara titik v1 dan 3 dan titik v2 dan 3. Elektroda tersebut terintegrasi dengan rangkain pengolah bioimpedance.Penggunaan frekuensi kerja sebesar $50 \mathrm{kHz}$ didasarkan pada hasil uji coba respon bioimpedance pada pundak terhadap 
bermacam-macam frekuensi arus yang distimulasikan [5].

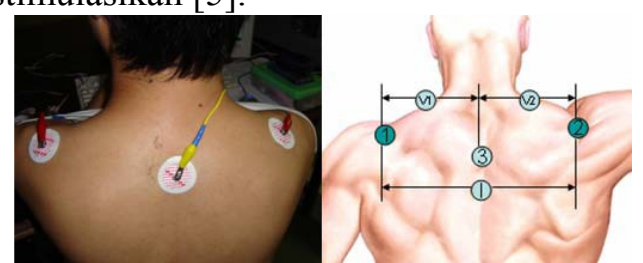

Gambar 3. Konfigurasi pemasangan elektroda

\section{B. Sistem Pengolah Bioimpedance}

Sinyal bioimpedanceakan diukur dengan menggunakan dua bagian rangkaian yang terintegrasi, yaitu rangkaian stimulasi dan rangkaian instrumentasi. Rangkaian stimulasi merupakan rangkaian pembangkit sumber arus bolak-balik dengan frekuensi $50 \mathrm{khz}$ dan amplitudo maksimum sebesar $0,5 \mathrm{~mA}_{\mathrm{rms}}$ [2]. Sumber arus ini kemudian akan diinjeksikan ke tubuh melalui elektroda. Bagian yang lainnya yaitu rangkaian instrumentasi. Rangkaian ini digunakan untuk mengukur beda potensial pada tubuh yang distimulasi. Besar tegangan yang terukur tersebut mewakili besarnya bioimpedance.Sistem ini dinamakan dengan sistem pengolah bioimpedance.Output dari rangkaian ini akan dikirim ke ADC mikrokontroler. Blok diagram dari sistem tersebut ditunjukan oleh Gambar 4.

Stimulasi yang diberikan yaitu berupa sumber arus sinusoidal sebesar $0,5 \mathrm{~mA}_{\mathrm{rms}}$ dengan frekuensi $50 \mathrm{kHz}$. Sumber arus ini dibangkitkan oleh rangkaian sine wave generator yang terhubung ke rangkaian Voltage Controlled Current Source (VCCS).Rangkaian sine wave generator terdiri dari pembangkit gelombang kotak dengan frekuensi $50 \mathrm{kHz}$, low pass filter dengan frekuensi cut-off $50 \mathrm{kHz}$, dan non-inverting amplifier.Tegangan sinusoidal yang dihasilkan dari rangkaian sine wave generator kemudian dimasukkan ke rangkaian VCCS jembatan arus Howland yang dimodifikasi. Rangkaian ini akan mengubah tegangan sinus menjadi arus. Frekuensi arus sama dengan frekuensi tegangan input, sedangkan besar arusnya diatur dengan menggunakan resistor variabel yang terpasang pada rangkaian.

Perubahan bioimpedance didapat dari besar tegangan elektroda positif (v2) terhadap referensi dan elektroda negatif (v1) terhadap
referensi.Kedua tegangan tersebut kemudian dikuatkan dengan seperangkat rangkaian instrumentation amplifier yang memiliki Common Mode Rejection Ratio (CMRR) yang tinggi. Karena hasil perubahan bioimpedance dimodulasikan pada frekuensi $50 \mathrm{KHz}$, pasti akan terdapat gangguan pada frekuensi rendah akibat dari adanya sinyal otot (EMG) yang ikut terukur dan pergerakan-pergerakan artefak. Untuk memperbaikinya, tegangan yang terukur dimasukkan ke rangkaian band pass filter dengan frekuensi center-nya terletak di sekitar $50 \mathrm{kHz}$. Nilai absolut dari bioimpedanceakan dihasilkan dengan menggunakan rangkaian rectifier. Rangkaian penguat tegangan akhir juga dipasang setelah rangkaian rectifier sebagai kalibrator tegangan agar didapatkan range tegangan keluaran antara 0 sampai 5 Volt.

Output dari rangkain sistem pengolah bioimpedance tersebut dijadikan input oleh sistem minimum Mikrokontroler. Hasil pengukuran bioimpedance ini kemudian dikirim ke sistem mikrokontroler dengan menggunakan 10 bit Analog to Digital Converter (ADC). Hasil pengukuran tersebut dikirim ke PC dengan menggunakan USB to Serial dengan Frekuensi sampling ADC diatur sebesar $100 \mathrm{hz}[1]$.

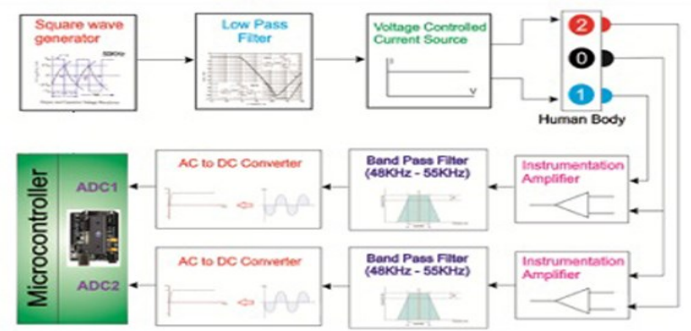

Gambar 4.Diagram blok sistem instrumentasi pengukuran bioimpedance.

\section{PID Controller dan Pengaturan Kecepatan Kursi Roda}

Hasil pembacaan tegangan bioimpedance oleh ADC internal mikrokontroler akan digunakan sebagai set point pada kontroler PID untuk mengatur pergerakan motor DC yang terpasang pada kursi roda. Kontroler ini berguna untuk menstabilkan kecepatan motor saat diberi beban yang berbeda-beda, sehingga kursi roda mampu bergerak sesuai dengan mode kecepatan yang diinginkan. Kontroler PID yang digunakan adalah PID digital yang sudah 
terintegrasi di dalam program mikrokontroler.Kontroler PID membutuhkan feedback untuk menjalankan fungsi kontrolnya. Karena yang dikontrol adalah kecepatan, maka sebuah sensor rotary encoder dipasang pada poros motor untuk mendeteksi kecepatan putaran motor.Keluaran dari sensor ini yaitu berupa gelombang kotak yang frekuensinya berubah-ubah sesuai dengan besar kecepatan putaran motor.Untuk mengukur kecepatan dari putaran motor, keluaran dari sensor ini bisa langsung dihubungkan ke mikrokontroler dan dihitung besar frekuensinya. Namun untuk mempermudah kerja mikrokontroler, keluaran gelombang kotak dari sensor ini diubah menjadi tegangan DC terlebih dahulu dengan menggunakan rangkaian frequency to voltage converter $(f$ to $v)$. Tegangan keluaran dari rangkaian ini kemudian diubah menjadi data digital dengan menggunakan ADC. Diagram blok keseluruhan sistem ditunjukkan pada Gambar 5.

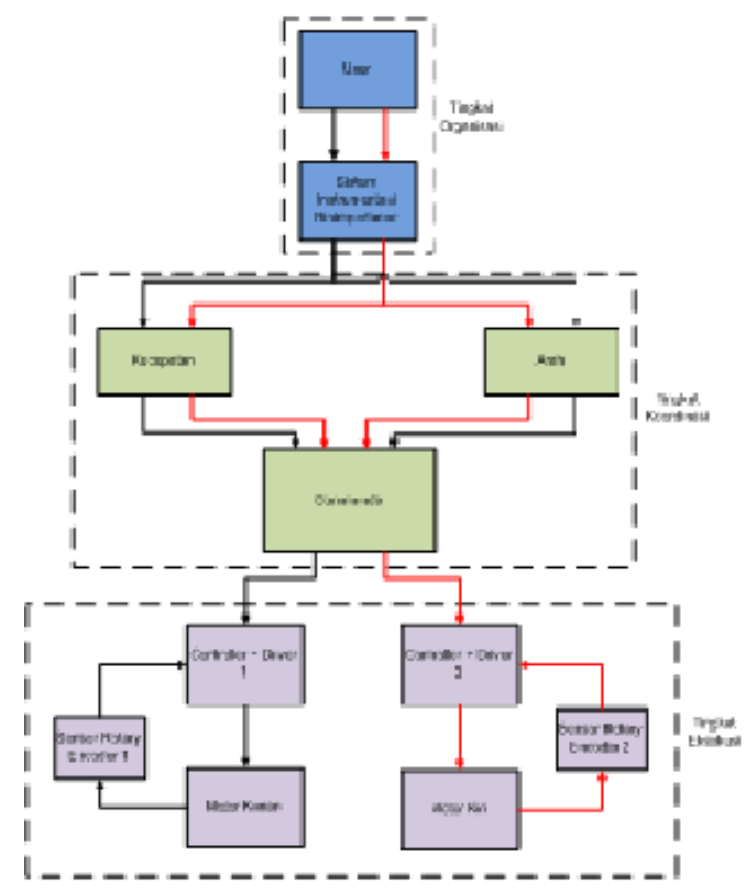

Gambar 5. Diagram blok keseluruhan sistem

Bioimpedance tubuh ini akan diolah oleh rangkaian pengkondisi sinyal, sehingga di hasilkan tegangan keluaran sebesar 0 - 5 Volt. Tegangan tersebut akan dijadikan input oleh mikrokontroler untuk mengendalikan gerak dari kursi roda. Masing-masing bahu akan menghasilkan satu tegangan input. Tegangan keluaran tersebut akan diklasifikasikan menjadi beberapa sinyal kontrol untuk kecepatan dan arah dari kursi roda. Sehingga akan didapatkan tiga jenis pengklasifikasian kecepatan gerak dari kursi roda, yaitu kursi roda dengan kecepatan lambat, sedang dan cepat.

Pengaturan kecepatan dari kursi roda ini dirancang berdasarkan keinginan (intentions) dari subjek yang akan menjalankan kursi roda. Dari percobaan awal yang dilakukan didapatkan kecepatan minimal dari kursi roda sebesar $24 \mathrm{Cm} / \mathrm{s}$ dan kecepatan maksimal dari kursi roda sebesar $58 \mathrm{Cm} / \mathrm{s}$. Dari range kecepatan yang dihasilkan tersebut, maka di buat 3 klasifikasi (mode) kecepatan dari kursi roda. Kecepatan mode 1 (lambat) dengan range kecepatan $30 \mathrm{Cm} / \mathrm{s}$, kecepatan mode 2 (sedang) dengan range kecepatan $40 \mathrm{Cm} / \mathrm{s}$ dan kecepatan mode 3 (cepat) dengan range kecepatan $50 \mathrm{Cm} / \mathrm{s}$.

Proses diawali dengan inisialisasi yang bertujuan untuk membuat setingan awal terhadap sistem. Kemudian dilakukan proses pengukuran dan pembacaan dari bioimpedance tubuh. Bioimpedance ini akan dijadikan input dalam mengontrol gerakan kursi roda. Perintah untuk maju dan belok berbeda.Perintah maju menggunakan kedua bahu sedangkan perintah belok hanya menggunakan satu bahu. Apabila kedua output bioimpedance dari masingmasing bahu yang diberikan besar dari threshold maka kursi roda bergerak maju dengan tingkatan kecepatan yang telah ditentukan. Proses yang sama juga digunakan untuk menambah kecepatan kursi roda. Sedangkan apabila hanya satu output bioimpedance dari salah satu bahu yang melebihi threshold dan lamanya besar dari 3 detik maka akan terdeteksi sebagai perintah belok dari kursi roda. Pada penelitian ini diberikan threshold sebesar 3 Volt. Mikrokontroler akan mengeksekusi perintah ketika tegangan input lebih besar dari 3 volt. Dan untuk menghasilkan sinyal impulse dilakukan deteksi tepi turun. Untuk lebih jelasnya mengenai proses perintah maju bisa dilihat pada Gambar 6 . 


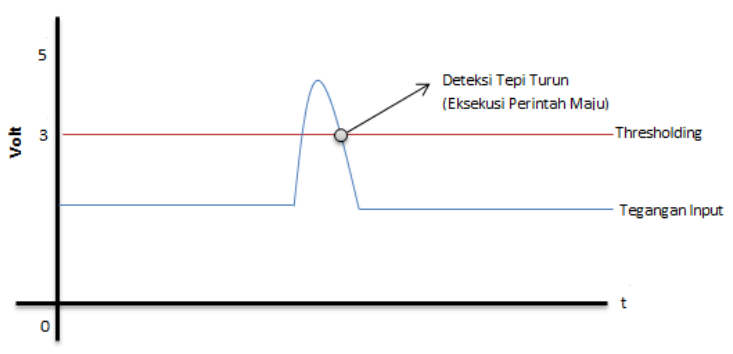

Gambar 6. Proses Eksekusi Perintah Maju

Untuk menghitung besarnya kecepatan motor digunakan rumus sebagai berikut:

$$
\mathrm{V}=\omega \mathrm{R} ; \mathrm{V}=2 \pi \mathrm{fR}
$$

$\mathrm{F}$ merupakan frekuensi yang didapatkan dari output sensor rotary encoder yang dipasang sebagai feedback pada motor DC, sedangkan R merupakan jari-jari dari kursi roda.

Untuk melihat respon Controller PID yang digunakan,pengambilan data kecepatan kursi roda dilakukan saat kondisi kursi roda tanpa beban dan saat kursi roda diberi beban dengan menggunakan dua orang subjek untuk menjalankan kursi roda secara bergantian.Percobaan tanpa beban dan berbeban masing-masing dilakukan sepuluh kali percobaan. Setelah dilakukan kalibrasi, subjek diminta untuk menjalankan kursi roda dengan memanfaatkan sinyal bioimpedace tubuh sebagai perintah kontrol dengan berbagai jenis kecepatan yang ada.Kemudian data kecepatan kursi roda tersebut dikirim ke PC melalaui komunikasi serial yang ada pada sistem minimum mikrokontroler. Waktu pengambilan data selama 10 detik untuk setiap percobaan dengan frekuensi sampling $50 \mathrm{~Hz}$. Semua data tersebut disimpan dalam format TXT.

\section{HASIL PENELITIAN}
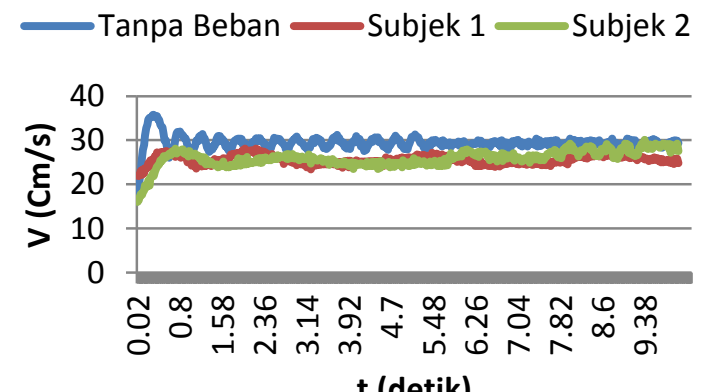

$t$ (detik)
Gambar 7. Hasil Kecepatan Mode 1

(Lambat) Roda Sebelah Kanan

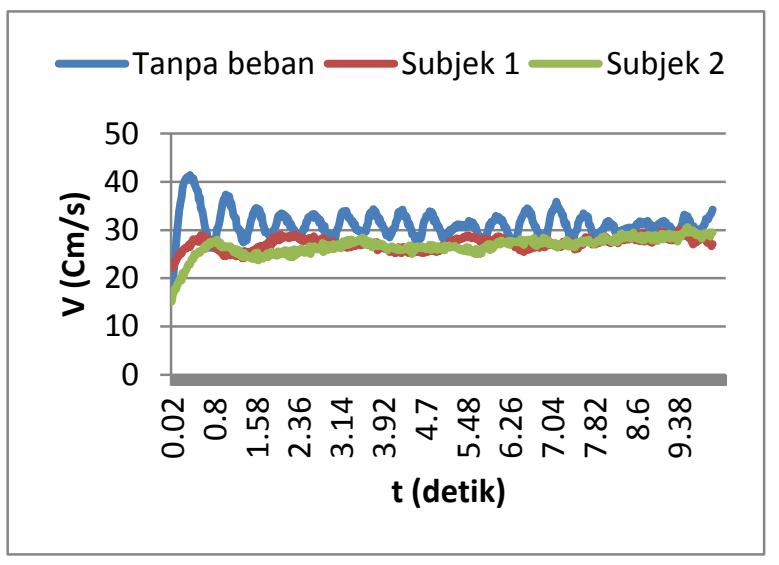

Gambar 8. Hasil Kecepatan Mode 1 (Lambat) Roda Sebelah Kiri

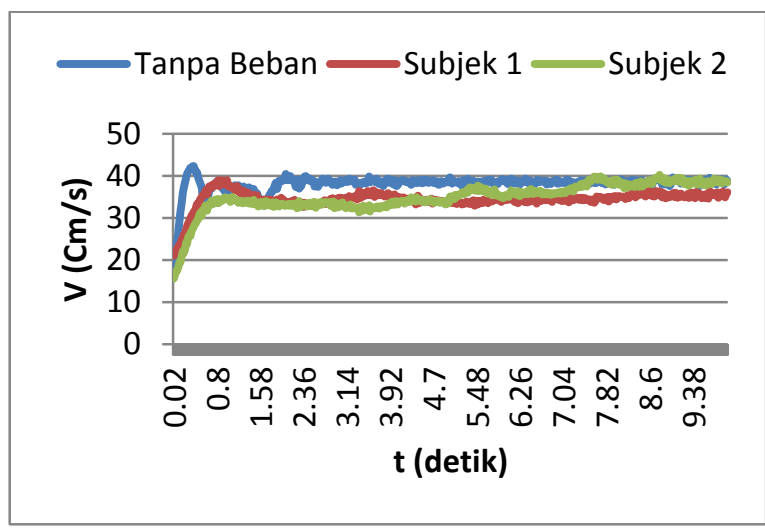

Gambar 9.Hasil Kecepatan Mode 2 (Sedang) Roda Sebelah Kanan

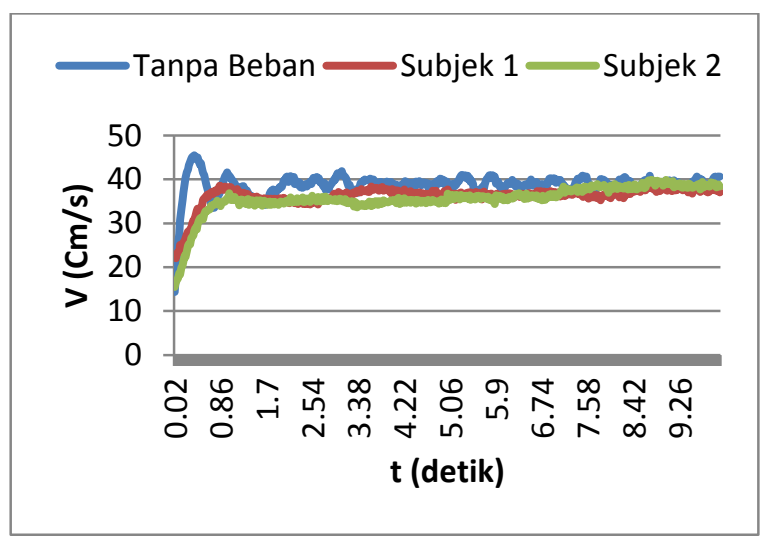

Gambar 10.Hasil Kecepatan Mode 2 (Sedang) Roda Sebelah Kiri 


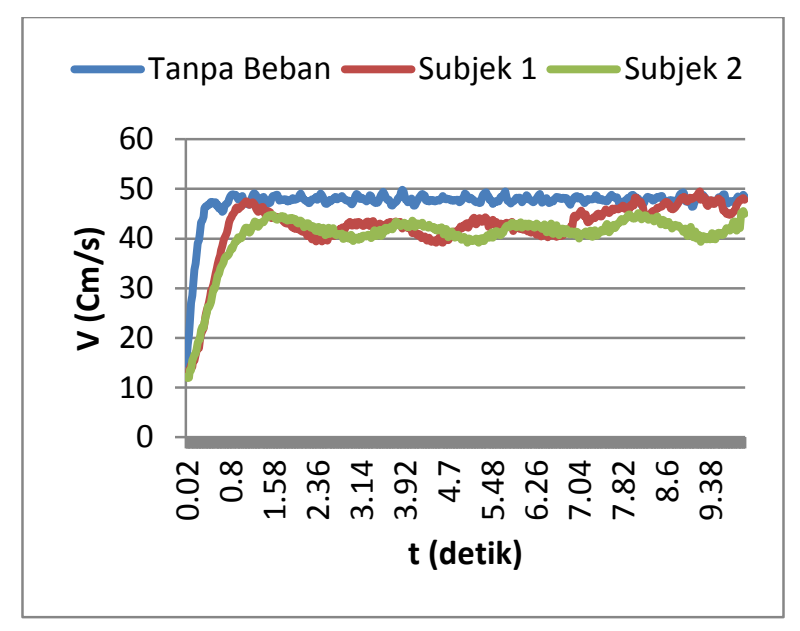

Gambar 11.Hasil Kecepatan Mode 3

(Cepat) Roda Sebelah Kanan

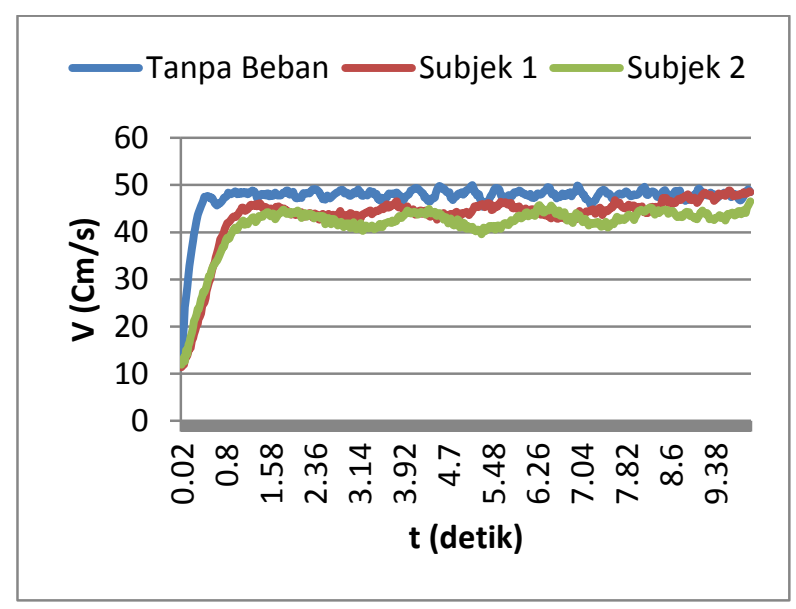

Gambar 12. Hasil Kecepatan Mode 3

(Cepat) Roda Sebelah Kiri

\section{PEMBAHASAN}

\section{A. Kecepatan Mode 1 (Lambat)}

Kecepatan kursi roda dengan mode 1 (lambat) ini merupakan klasifikasi jenis kecepatan yang pertama dari kursi roda. Apabila kedua bahu digerakan kedepan selama sesaat dan mengakibatkan tegangan input melebihithreshold, kemudian bahu kita kembalikan ke posisi awal maka kursi roda akan bergerak dengan kecepatan mode 1 . Kursi roda akan terus bergerak dengan kecepatan ini sampai ada perintah selanjutnya yang kita berikan. Kecepatan mode 1 ini merupakan kecepatan yang paling lambat jenis kecepatan kursi roda lainnya.Dari hasil eksperimen yang dilakukan, didapatkan hasil kecepatan kursi roda seperti pada Gambar 7 danGambar 8.

Nilai kecepatan kursi roda mode 1 ini diatur sebesar $30 \mathrm{Cm} / \mathrm{s}$. dari hasil percobaan yang dilakukan terlihat respon kecepatan dari kursi roda. Dimana kecepatan kursi roda perlahan menuju nilai target (steady state) yang telah ditentukan baik disaat kondisi tanpa beban dan ketika kursi roda diberi beban. Nilai eror ratarata kecepatan kursi roda mode 1 (lambat) saat Tanpa Beban selama 10 detik adalah sebesar $0.576 \mathrm{Cm} / \mathrm{s}$ untuk roda kanan dan $1.213 \mathrm{Cm} / \mathrm{s}$ untuk roda kiri. Untuk Subjek 1, eror rata-rata kecepatan kursi roda adalah sebesar $4.46 \mathrm{Cm} / \mathrm{s}$ untuk roda kanan dan 2.807 untuk roda kiri. Eror rata-rata kecepatan kursi roda untuk Subjek 3 adalah sebesar $4.107 \mathrm{Cm} / \mathrm{s}$ untuk roda kanan dan $3.322 \mathrm{Cm} / \mathrm{s}$ untuk roda kiri. Terdapat perbedaan nilai eror kecepatan kursi roda karena pengaruh berat beban dari kursi roda.

\section{B. Kecepatan Mode 2 (Sedang)}

Kecepatan kursi roda mode 2 merupakan jenis kecepatan kursi roda yang kedua dari klasifikasi jenis kecepatan kursi roda yang ada.Kecepatan dengan mode 2 ini baru bisa terjadi setelah melalui kecepatan mode 1 . Ketika kursi roda bergerak dengan kecepatan mode 1 maka untuk meningkatkan kecepatannya menjadi mode 2 kedua bahu digerakan lagi kedepan selama sesaat dan mengakibatkan tegangan input melebihi threshold, kemudian bahu kita kembalikan ke posisi awal maka kursi roda akan bergerak dengan kecepatan mode 2. Kursi roda akan terus bergerak dengan kecepatan ini sampai ada perintah selanjutnya yang kita berikan. Dari hasil eksperimen yang dilakukan, didapatkan hasil kecepatan kursi roda seperti pada gambar 9 dan 10 .

Nilai kecepatan kursi roda mode 2 ini diatur sebesar $40 \mathrm{Cm} / \mathrm{s}$. dari hasil percobaan yang dilakukan terlihat respon kecepatan dari kursi roda. Dimana kecepatan kursi roda perlahan menuju nilai target (steady state) yang telah ditentukan baik disaat kondisi tanpa beban dan ketika kursi roda diberi beban. Nilai eror rata-rata kecepatan kursi roda mode 2 (Sedang) saat Tanpa Beban selama 10 detik 
adalah sebesar $1.85 \mathrm{Cm} / \mathrm{s}$ untuk roda kanan dan $1.239 \mathrm{Cm} / \mathrm{s}$ untuk roda kiri. Untuk Subjek 1, eror rata-rata kecepatan kursi roda adalah sebesar $5.517 \mathrm{Cm} / \mathrm{s}$ untuk roda kanan dan 3.779 untuk roda kiri. Eror rata-rata kecepatan kursi roda untuk Subjek 3 adalah sebesar 5.034 $\mathrm{Cm} / \mathrm{s}$ untuk roda kanan dan $4.41 \mathrm{Cm} / \mathrm{s}$ untuk roda kiri. Terdapat perbedaan nilai eror kecepatan kursi roda karena pengaruh berat beban dari kursi roda.

\section{Kecepatan Cepat}

kecepatan kursi roda mode 3 merupakan jenis kecepatan kursi roda yang paling cepat dari klasifikasi jenis kecepatan kursi roda yang ada. Kecepatan dengan mode 3 ini baru bisa terjadi setelah melalui kecepatan mode 2 . Ketika kursi roda bergerak dengan kecepatan mode 2 maka untuk meningkatkan beban dan ketika kursi roda diberi beban. Nilai eror ratarata kecepatan kursi roda mode 3 (Cepat) saat Tanpa Beban selama 10 detik adalah sebesar $2.617 \mathrm{Cm} / \mathrm{s}$ untuk roda kanan dan $2.513 \mathrm{Cm} / \mathrm{s}$ untuk roda kiri. Untuk Subjek 1, eror rata-rata kecepatan kursi roda adalah sebesar 7.593 $\mathrm{Cm} / \mathrm{s}$ untuk roda kanan dan $6.581 \mathrm{Cm} / \mathrm{s}$ untuk roda kiri. Eror rata-rata kecepatan kursi roda untuk Subjek 3 adalah sebesar $9.364 \mathrm{Cm} / \mathrm{s}$ untuk roda kanan dan $8.401 \mathrm{Cm} / \mathrm{s}$ untuk roda kiri. Terdapat perbedaan nilai eror kecepatan kursi roda karena pengaruh berat beban dari kursi roda.

\section{KESIMPULAN}

Pemanfaatan sinyal bioelectrical impedance atau bioimpedance sebagai control commands pengaturan kecepatan gerak dari kursi roda berhasil direalisasikan pada penelitian ini dengan tingkat keberhasilan 86.7 $\%$. Dengan metode PID Controller, kecepatan gerak dari kursi roda ini diklasifikasikan menjadi 3 jenis kecepatan, yaitu kecepatan Lambat dengan kecepatan sebesar $30 \mathrm{Cm} / \mathrm{s}$, kecepatan Sedang dengan kecepatan $40 \mathrm{Cm} / \mathrm{s}$ dan kecepatan Cepat dengan kecepatan 50 $\mathrm{Cm} / \mathrm{s}$. Kecepatan kursi roda ini ditentukan berdasarkan keinginan (instentions) dari pengguna kursi roda. Selain bergerak lurus, kursi roda juga bisa berbelok ke arah kiri dan kanan sesuai dengan keinginan dari pengguna kursi roda.

\section{DAFTAR PUSTAKA}

[1]. Bejo, Agus.,"C \& AVR Rahasia kemudahan Bahasa $C$ Dalam Mikrokontroler ATMega8535", Graha Ilmu, Yogyakarta, 2008.

[2]. Ermado, Rico “Aplikasi Bioelectrical Impedance Sebagai Perintah Kontrol Gerakan Pada Kursi Roda Elektrik", Tugas Akhir., Institut Tekonologi Sepuluh Nopember, Surabaya. 2011.

[3]. Tabuenca, Javier Gracia, "Multichannel Bioimpedance Measuremet, Master science Thesis", Tampere University Of Technology, 2009

[4]. Yunfei, H. "Wheelchair Control Based on Bioimpedance". International Journal of Applied Biomedical Engineering Vol.3, No.1, pp.13-15, 2010.

[5]. Y. F. Huang, P. Phukpattaranont, B. Wongkittisuksa, and S. Tanthanuch, "Development of a bioimpedance-based human machine interface for wheelchair control", Proceedings of the ECTI International Conference (ECTICON 2009), pp. 1032-1035, Pattaya, Thailand, May 2009.

\section{Biodata Penulis}

Juli Sardi, Menamatkan S1 di Jurusan Teknik Elektro Universitas Negeri Padang (UNP) tahun 2010. Pendidikan S2 bidang Elektronika diselesaikan di Institut teknologi Sepuluh Nopember (ITS) tahun 2013.Saat ini penulis terdaftar sebagai dosen Teknik Elektro Universitas Negeri Padang.

Ali Basrah Pulungan, Menamatkan S1 di Jurusan Teknik Elektro Universitas Sumatera Utara (USU) tahun 1999. Pendidikan S2 bidang Teknik Tenaga Listrik diselesaikan di Universitas Gajah Mada (UGM) tahun 2007. Saat ini penulis terdaftar sebagai dosen Teknik Elektro Universitas Negeri Padang. 